\title{
PRODUCTIVITY OF IRRIGATED JAMBU UNDER SOIL-WATER STRESSES AND NITROGEN DOSES
}

\author{
William L. C. de Aviz ${ }^{*}$, Joaquim A. de Lima Junior ${ }^{2}$, André L. P. da Silva ${ }^{3}$, Pedro D. de Oliveira ${ }^{2}$, \\ Cândido M. P. Gama ${ }^{1}$
}

${ }^{1 *}$ Corresponding author. Universidade Federal Rural da Amazônia - UFRA/ Belém - PA, Brasil.

E-mail: william.aviz@gmail.com | ORCID ID: https://orcid.org/0000-0002-7567-6297

\section{KEYWORDS}

Acmella oleracea (L.) R.K., tensiometry, dripping, nitrogen fertilization.

\begin{abstract}
Jambu (Acmella oleracea (L.) R.K.) is a short-cycle leafy vegetable from the Amazon region, which needs an adequate availability of water and nutrients, mainly nitrogen, to obtain a rapid mass increase. This research aimed to study the effect of different soilwater stresses and nitrogen doses on jambu cultivation in the state of Pará. The experiments were conducted at the Igarapé-Açu experimental farm of the Federal Rural University of Amazonia (UFRA). The Jamburana variety was used in a $10 \times 10 \mathrm{~cm}$ spacing, using a randomized block design in a $4 \times 4$ factorial scheme with three replications. Each plot had a dimension of $0.4 \times 0.5 \mathrm{~m}\left(0.2 \mathrm{~m}^{2}\right)$, totaling 20 plants in 4 rows, but only the plants of the central rows were useful. Treatments consisted of four soil-water stresses $(12,18,24$, and $30 \mathrm{kPa})$ as an indication of the irrigation time (critical stress), using drip irrigation, and four nitrogen doses $\left(0,50,100\right.$, and $\left.150 \mathrm{~kg} \mathrm{ha}^{-1}\right)$. The use of soil-water stress of $12 \mathrm{kPa}$ associated with nitrogen fertilization at a dose of 150 $\mathrm{kg} \mathrm{ha}^{-1}$ is recommended for better development and production of jambu under the conditions this experiment was conducted.
\end{abstract}

\section{INTRODUCTION}

Jambu is an unconventional vegetable native to the Amazon region, originating in the Amazon basin, belonging to the family Asteraceae, with extreme importance in the regional cuisine and for medicinal purposes in the treatment of various diseases (Gusmão \& Gusmão, 2013).

In addition, Barbosa et al. (2016) stated that spilanthol, a substance found in jambu, has aroused the interest of pharmaceutical and cosmetic markets due to its biological activities such as analgesic, antinociceptive, antioxidant, anti-inflammatory, antimutagenic, antiwrinkle, antifungal, bacteriostatic, insecticidal, antimalarial, anti-larvicidal against Aedes aegypti and Helicoverpa zea neonates, and anti-molluscicide. It can be absorbed through the skin, endothelial intestine, oral mucosa, and blood-brain barrier.

Vegetable production and quality may be limited by water deficit at certain times of the year (August to December) or high rainfall (January to July) due to the high variability of precipitation in the region (Pacheco \& Bastos, 2008).
Water is one of the determining factors for food production and has a direct influence on agricultural production, being important to perform the ideal water replacement in order to obtain high productivity rates (Dutra et al., 2018). Thus, irrigation is one of the agricultural practices that provide production in regions with low water availability and increased production per area where this technique is already used.

However, the increased use of irrigation in agricultural systems has been causing environmental problems due to the misuse of this technique, mainly related to waste of water, making it necessary to manage irrigation properly (Foley et al., 2011). Knowing the irrigation time and the ideal quantity of water to be applied to each crop is essential to prevent water stress and increase productivity, in addition to minimizing the waste of water and nutrient leaching and maximizing water use efficiency (Azevedo et al., 2014; Aviz et al., 2019).

In order to obtain the ideal water depth and achieve satisfactory productivity, Valeriano et al. (2016) and Araújo et al. (2018) evaluated lettuce and arugula productivity,

\footnotetext{
${ }^{1}$ Universidade Federal Rural da Amazônia - UFRA/ Belém - PA, Brasil.

${ }^{2}$ Universidade Federal Rural da Amazônia - UFRA/ Capanema - PA, Brasil.

${ }^{3}$ Universidade Estadual Paulista - UNESP/ São Paulo - SP, Brasil.
} 
respectively, submitted to different irrigation depths and observed maximum production values close to the replacement factor of $100 \%$ of the evapotranspiration. Geisenhoff et al. (2016) also studied lettuce productivity subjected to different soil-water stresses and found a maximum productivity value at a stress of $12 \mathrm{kPa}$, but with higher water use efficiency with intermediate stresses of 34 and $45 \mathrm{kPa}$, reaching 579.87 and $471.71 \mathrm{~kg} \mathrm{ha}^{-1} \mathrm{~mm}^{-1}$, respectively.

However, in addition to water availability as a key factor in achieving high productivity, nutrition is also another indispensable factor in vegetable production. Leafy vegetables have a direct effect of nitrogen on plant growth and, consequently, productivity (Mota et al., 2016; Rezende et al., 2017; Farias et al., 2015; Vieira Filho et al., 2017).

Rodrigues et al. (2014) found a significant difference of jambu production in Pariqueira-Açu, São Paulo, Brazil, as a function of nitrogen doses; the treatment with the highest dose showed a $90 \%$ increase for fresh matter production in relation to the treatment with the total omission of this element. Borges et al. (2014) analyzed the productivity of jambu cultivars influenced by organic and mineral fertilization and found maximum values of $2.98 \mathrm{~kg}$ $\mathrm{m}^{2}$ using mineral fertilizer at a dose of $69.9 \mathrm{~g} \mathrm{~m}^{2}$ of nitrogen.

Thus, this study aimed to evaluate the effect of different soil-water stresses and nitrogen doses on the productivity of drip-irrigated jambu in Igarapé-Açu, PA, Brazil.

\section{MATERIAL AND METHODS}

The experiment was carried out in Igarapé-Açu, northeast region of the state of Pará, Brazil, from July to September 2016 under field conditions and consecutive plantations at the Experimental Farm of the Federal Rural University of Amazonia (UFRA), which has geographical coordinates of $1^{\circ} 07^{\prime} 48.47^{\prime \prime} \mathrm{S}$ and $47^{\circ} 36^{\prime} 45.31^{\prime \prime} \mathrm{W}$, with an altitude of $54 \mathrm{~m}$.

The local soil is classified as a sandy textured dystrophic Yellow Argisol. The mean soil density was 1.60 $\mathrm{g} \mathrm{cm}^{-3}$, and the results of the fertility and particle size analysis of the experimental area were obtained from a composite soil sample collected at a depth of 0-0.2 m (Table 1).

TABLE 1. Soil physical and chemical properties of the experimental area.

\begin{tabular}{|c|c|c|c|c|c|c|c|c|c|c|}
\hline \multicolumn{3}{|c|}{ Particle size } & \multicolumn{8}{|c|}{ Chemical analysis } \\
\hline Sand & Silt & Clay & \multirow{2}{*}{$\mathrm{pH} \mathrm{H} \mathrm{H}_{2} \mathrm{O}$} & \multirow{2}{*}{$\begin{array}{c}\mathrm{OM} \\
\mathrm{g} \mathrm{kg}^{-1}\end{array}$} & \multirow{2}{*}{$\begin{array}{l}\mathrm{N} \\
\%\end{array}$} & $\mathrm{P}$ & $\mathrm{K}$ & $\mathrm{Na}$ & $\mathrm{Ca}$ & $\mathrm{Mg}$ \\
\hline & $\mathrm{g} \mathrm{kg}$ & & & & & \multicolumn{3}{|c|}{$\mathrm{mg} \mathrm{dm}{ }^{-3}$} & \multicolumn{2}{|c|}{$\mathrm{cmol}_{\mathrm{c}} \mathrm{dm}^{-3}$} \\
\hline 801 & 19 & 180 & 5.9 & 13.76 & 0.07 & 37 & 19 & 30 & 2.1 & 0.9 \\
\hline
\end{tabular}

Plowing and harrowing were carried in the area and then, beds with $0.2 \mathrm{~m}$ height and an area of $0.25 \mathrm{~m}^{2}$ were made. Liming was not necessary because the base saturation was within the ideal range for cultivation (70-80\%). Fertilization was performed based on soil chemical analysis and following the recommendation by Cravo et al. (2007). Triple superphosphate was applied during the preparation of the pits, with a dose to provide $100 \mathrm{~kg} \mathrm{ha}^{-1}$ of $\mathrm{P}_{2} \mathrm{O}_{5}$. Topdressing fertilization was split into three applications and performed at 10,17 , and 24 days after seedling planting. Fertilizers used in the area were potassium chloride at a dose of $120 \mathrm{~kg} \mathrm{ha}^{-1}$ of $\mathrm{K}_{2} \mathrm{O}$ and the nitrogen at doses of 0,50 , 100 , and $150 \mathrm{~kg} \mathrm{ha}^{-1}$ of $\mathrm{N}$, as established in the treatments.

The experimental design was a randomized block design in a $4 \times 4$ factorial scheme, with three replications. Treatments consisted of four soil-water stresses $(12,18,24$, and $30 \mathrm{kPa})$ and four nitrogen doses $\left(0,50,100\right.$, and $\left.150 \mathrm{~kg} \mathrm{ha}^{-1}\right)$.

The cultivar Jamburana, which has a cycle of approximately 70 to 80 days, was used. Seedlings were obtained from family producers of Igarapé-Açu and produced in 128-cell Styrofoam trays filled with organic compost with good phytosanitary characteristics. Transplanting was performed at 31 days after sowing. The spacing used was $10 \times 10 \mathrm{~cm}$, with plots with dimensions of $0.4 \times 0.5 \mathrm{~m}\left(0.2 \mathrm{~m}^{2}\right)$, totaling twenty plants arranged in four rows of five plants. Central plants were considered useful (useful area with 10 plants).
After transplanting, plants were irrigated for 10 days to a better adaptation to field conditions. During this period, an irrigation depth of $3.19 \mathrm{~mm}$ was applied per day, with no stress measurement.

Manual weeding procedures were carried out in the beds and with a hoe between beds to control weeds. There was no incidence of pests and diseases during the experimental period. Harvesting was performed at 77 days after planting.

Irrigation was performed using pressurecompensating dripline hoses of additive polyethylene, with inline emitters spaced at $20 \mathrm{~cm}$, flow rate of $1.2 \mathrm{~L} \mathrm{~h}^{-1}$ each, nominal diameter of $16 \mathrm{~mm}$, working pressure of $6 \mathrm{mWC}$ at the end of the hose. Drip hoses were connected to polyethylene bypass lines (DN 16), which were connected to PVC pipes (DN 50; PN40), which, in turn, were connected to the main line via electrically operated solenoid valves via the controller installed on the control head. A $5000 \mathrm{~L}$ water tank was used for the irrigation system to store the water used in the experiment. Also, a $1.5 \mathrm{hp}$ electric pump, a 120 mesh disc filter, and a pressure regulating valve, set to work with up to $6 \mathrm{mWC}$ inserted into the main pipe outlet, were used.

Critical stress was determined using two puncture tensiometer devices installed for each stress established in the treatments $(12,18,24$, and $30 \mathrm{kPa})$, together with a dose 
of $100 \mathrm{~kg} \mathrm{ha}^{-1}$ of nitrogen, which was the recommended fertilizer dose. These tensiometers were installed at a depth of $15 \mathrm{~cm}$, being positioned between two plants in the plant row, and indicated the time to irrigate. Stress measurements were performed once a day in the morning (9:00 h) using a digital puncture tensiometer with a sealing rubber inserted on its top.
Irrigations were performed when the tensiometer mean reached the critical stress established in the treatments, always seeking to raise soil moisture to its field capacity, corresponding to a stress of $10 \mathrm{kPa}\left(0.240 \mathrm{~cm}^{3} \mathrm{~cm}^{-3}\right)$.

Irrigation management was based on the soil-water characteristic curve obtained at a depth of 0-20 cm (Figure 1), following the methodology of Andrade Junior et al. (2007), being then adjusted by the van Genuchten (1980) model.

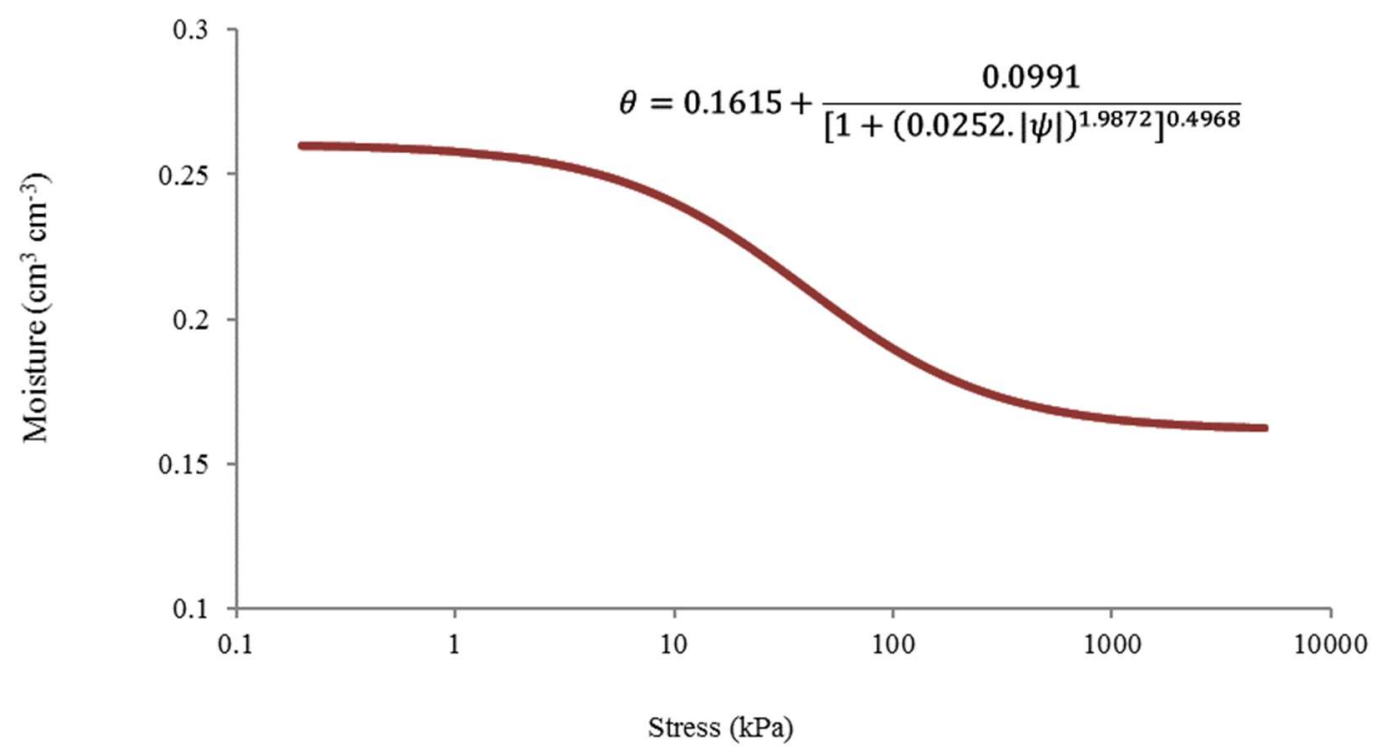

FIGURE 1. Soil-water retention curve.

The distribution uniformity coefficient (DUC) and application efficiency were calculated after the irrigation system was installed, following the methodology proposed by Calgaro \& Braga (2008).

Considering the effective depth of the root system equal to $20 \mathrm{~cm}$ (Gusmão \& Gusmão, 2013), the net irrigation depth was calculated by [eq. (1)].

$$
N I D=(\theta c c-\theta \text { current }) \cdot z
$$

Where:

NID is the net irrigation depth (mm);

Occ is the soil moisture at field capacity $\left(\mathrm{cm}^{3} \mathrm{~cm}^{-3}\right)$;

Ocurrent is the soil moisture at the time of irrigation $\left(\mathrm{cm}^{3} \mathrm{~cm}^{-3}\right)$, and

$\mathrm{z}$ is the effective depth of the root system (mm). [eq. (2)].

Then, the gross irrigation depth was calculated by

$$
G I D=\frac{N I D}{E a \cdot D U C}
$$

Where:

GID is the gross irrigation depth (mm);

Ea is the application efficiency, and

DUC is the distribution uniformity coefficient for the water of the irrigation system.
Subsequently, the irrigation system working time was calculated by [eq. (3)] in order to perform the water replacement in the treatments.

$$
T=\frac{G I D \cdot A}{e . q a}
$$

Where:

$\mathrm{T}$ is the irrigation system working time of each treatment aiming to increase the moisture to field capacity (h);

$A$ is the area occupied per plot $\left(\mathrm{m}^{2}\right)$;

$\mathrm{e}$ is the number of emitters per plot, and

qa is the mean flow of emitters $\left(\mathrm{L} \mathrm{h}^{-1}\right)$.

Temperature, air humidity, and precipitation data were collected from a Vantage pro2 automatic weather station installed in the experimental area.

The response variables plant height $(\mathrm{PH})$, shoot fresh matter (SFM), productivity (PROD), and water use efficiency (WUE) were analyzed to evaluate the effect of soil-water stress and nitrogen doses.

Plant height was measured at the time of harvest, being determined from the plant collar using a measuring tape. The shoot fresh matter was determined using a precision scale shortly after harvest. Productivity was estimated in $\mathrm{g} \mathrm{m}^{-2}$ by multiplying the shoot fresh matter by plant population in one square meter, while water use efficiency was obtained by dividing the productivity obtained per area by the total water depth applied in each treatment. 
The data were subjected to analysis of variance and means compared by the Tukey test at 5 and $1 \%$ probability. A regression analysis was performed when there was significance.

\section{RESULTS AND DISCUSSION}

During the experiment, the mean daily air temperature and humidity were $27.8{ }^{\circ} \mathrm{C}$ and $71.1 \%$, respectively. During this period, temperature ranged from 21.3 to $33.9{ }^{\circ} \mathrm{C}$, while humidity ranged from 41 to $93 \%$. These data show a variation of more than $12{ }^{\circ} \mathrm{C}$ in temperature and more than $50 \%$ in humidity throughout the experiment. According to Gusmão \& Gusmão (2013), jambu grows well in hot and humid climates, with temperatures ranging from 25 to $35^{\circ} \mathrm{C}$, relative humidity around $80 \%$, and 2,600 hours of sunlight annually, being one of the few vegetables not harmed by excessive rainfall. Thus, the experiment was conducted under ideal conditions for proper crop development.

Water depths applied before and after treatment differentiation, as well as precipitations during the experimental period, total water supplied to the crop until harvest, number of irrigations, mean irrigation frequency, and daily water demand during treatment differentiation are shown in Table 2.

TABLE 2. Soil-water stress at a depth of $0.15 \mathrm{~m}$, water depth applied before (Begin.) and after (Irrig.) treatment differentiation, precipitation (Prec.), total water depths (Total), number of irrigations (NI), and mean irrigation frequency (IF), daily water demand (WD).

\begin{tabular}{cccccccc}
\hline \multicolumn{7}{c}{ Water depth $(\mathrm{mm})$} \\
\hline Stress & Begin. & Irrig. & Prec. & Total & NI & IF (day) & WD (mm/day) \\
\hline $12 \mathrm{kPa}$ & 31.9 & 36.98 & 109.2 & 178.08 & 24 & 1.46 & 3.96 \\
$18 \mathrm{kPa}$ & 31.9 & 29.49 & 109.2 & 170.59 & 14 & 2.5 & 3.79 \\
$24 \mathrm{kPa}$ & 31.9 & 13.79 & 109.2 & 154.89 & 4 & 8.75 & 3.44 \\
$30 \mathrm{kPa}$ & 31.9 & 12.52 & 109.2 & 153.62 & 3 & 11.67 & 3.41 \\
\hline
\end{tabular}

The data in Table 3 showed a linear behavior in relation to water consumption per treatment, similar to that observed by Geisenhoff et al. (2016) in an experiment with drip-irrigated lettuce with different stresses, in which the total applied depth decreased as the soil-water stress increased.
An interaction was observed between the factors stress and nitrogen dose (Table 3 ) for the shoot fresh matter, productivity, and water use efficiency. No significant difference for height was observed for the interaction between these factors, but there was an isolated effect only for nitrogen dose.

TABLE 3. Summary of analysis of variance for plant height (PH), shoot fresh matter (SFM), productivity (PROD), and water use efficiency (WUE) of jambu plants as a function of soil-water stresses and nitrogen doses in Igarapé-Açu, Pará, Brazil.

\begin{tabular}{cccccc}
\hline \multirow{2}{*}{ Source of variation } & \multirow{2}{*}{ DF } & \multicolumn{3}{c}{ F-value } \\
\cline { 3 - 6 } & & PH & SFM & PROD & WUE \\
\hline Stress & 3 & $2.0462 \mathrm{~ns}$ & $127.9796^{* *}$ & $127.9796^{* *}$ & $52.4037^{* *}$ \\
Nitrogen & 3 & $5.0501^{* *}$ & $274.7800^{* *}$ & $274.7800^{* *}$ & $268.5446^{* *}$ \\
Stress $\times$ nitrogen & 9 & $0.3788 \mathrm{~ns}$ & $11.7051^{* *}$ & $11.7051^{* *}$ & $8.3287^{* *}$ \\
Blocks & 2 & $2.9448 \mathrm{~ns}$ & $3.0270 \mathrm{~ns}$ & $3.0270 \mathrm{~ns}$ & $2.8160 \mathrm{~ns}$ \\
Residual & 30 & & & & 6.03 \\
\hline CV\% & & 15.74 & 6.03 & 6.04 \\
\hline
\end{tabular}

**Significant at $1 \%$ probability; *significant at $5 \%$ probability; ${ }^{\text {ns }}$ not significant.

According to the analysis of variance, there was an interaction between factors, showing a linear behavior in which the total applied water depth influenced nitrogen absorption. For shoot fresh matter, productivity, and water use efficiency, treatments submitted to a stress of $12 \mathrm{kPa}$ and nitrogen dose of $150 \mathrm{~kg} \mathrm{ha}^{-1}$ had higher means when compared to the others, occurring a reduction in the variables as stresses increase.

Water depths and nitrogen doses influenced jambu development, evidencing the need for an ideal amount of water and nutrient to obtain a good crop development. Soil moisture maintained close to field capacity favored nitrogen use efficiency. Considering that water is the means of transport of nutrients to plants, the management that provided the highest amount of water and lowest irrigation frequency promoted the reduction of nitrogen losses by leaching and kept the soil consistently moist, which favored biomass accumulation.

Jambu showed a positive response to the increase of nitrogen doses, evidencing its importance in leafy vegetables. Nitrogen at a dose of $150 \mathrm{~kg} \mathrm{ha}^{-1}$ provided a high increment of fresh matter under all soil-water stresses, with a higher response of nitrogen fertilization at lower soil-water stresses.

Fresh matter production showed linear behavior for interaction between the factors soil-water stress and nitrogen dose, and the treatment with maximum fresh matter production consisted of the combination between the stress of $12 \mathrm{kPa}$ and nitrogen dose of $150 \mathrm{~kg} \mathrm{ha}^{-1}$, reaching a value of $39.0 \mathrm{~g} \mathrm{plant}^{-1}$ (Figure 2). These results showed that plants subjected to this treatment absorbed more nitrogen because soil moisture remained close to the field capacity, which favored the mass flow, soil aeration, solubilization, and nutrient availability (Marouelli et al., 2014).

Fresh matter decreases as soil-water stress increases, regardless of the used nitrogen dose. This effect is due to the difficulty that the plant has to absorb the water retained in the soil colloid at higher stresses, requiring higher energy expenditure. 


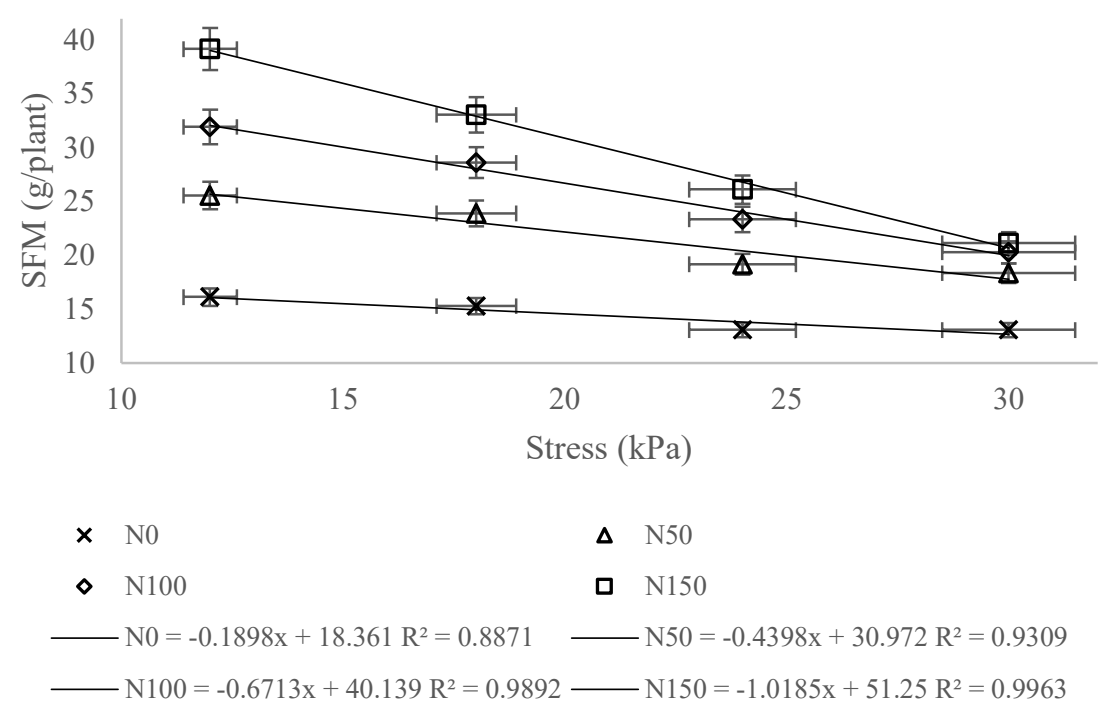

FIGURE 2. Jambu shoot fresh matter (SFM) as a function of different soil-water stresses (12, 18, 24, and $30 \mathrm{kPa})$ and nitrogen doses $\left(0,50,100\right.$, and $\left.150 \mathrm{~kg} \mathrm{ha}^{-1}\right)$. Igarapé-Açu, PA, Brazil, 2017.

The result of fresh matter found in this study presented behavior similar to that found by Silva et al. (2013), who worked with beet under different soil-water stresses and found a linear model for fresh matter production, with a maximum value at stress closer to field capacity $(15 \mathrm{kPa})$. Rodrigues et al. (2014) evaluated the influence of nitrogen and phosphorus fertilization on jambu production and found maximum fresh matter production (leaves and flowers) of 4,012.4 $\mathrm{g} \mathrm{m}^{2}$ at a dose of $112.5 \mathrm{~kg}$ $\mathrm{ha}^{-1}$ of nitrogen. These results confirm that water and nutrient availability is fundamental for the increase of fresh matter in jambu.

Plant height varied significantly only for the factor nitrogen doses and had a quadratic behavior (Figure 3 ). The regression analysis showed that the maximum height was found at a nitrogen dose of $57.13 \mathrm{~kg} \mathrm{ha}^{-1}$, resulting in the height of $15.46 \mathrm{~cm}$, from which the increased nitrogen doses led to a decrease in plant height. These results are different from those found by Favoreto \& Gilbert (2010), who observed that jambu could reach around 20 to $40 \mathrm{~cm}$ in height. Borges et al. (2014) and Souto et al. (2018) studied fertilization in the jambu crop and obtained higher plant height than that found in this study, with values of 37.36 and $35.42 \mathrm{~cm}$, respectively.

Similar to fresh matter, the variable productivity was significantly affected by the interaction between factors and showed linear behavior, reaching a maximum value of $39 \mathrm{t}$ $\mathrm{ha}^{-1}$ at a stress of $12 \mathrm{kPa}$ and nitrogen dose of $150 \mathrm{~kg} \mathrm{ha}^{-1}$ (Figure 4). The treatment with $12 \mathrm{kPa}$ favored the use of nitrogen fertilization by jambu plants, which responded with maximum productivity at the highest dose. The treatment with soil-water stress of $12 \mathrm{kPa}$ maintained the soil close to field capacity, demonstrating behavior similar to the results found by Geisenhoff et al. (2016) with lettuce and Lima Junior et al. (2012) with carrots, who performed irrigation management based on the soil and obtained maximum productivity at stresses close to field capacity.

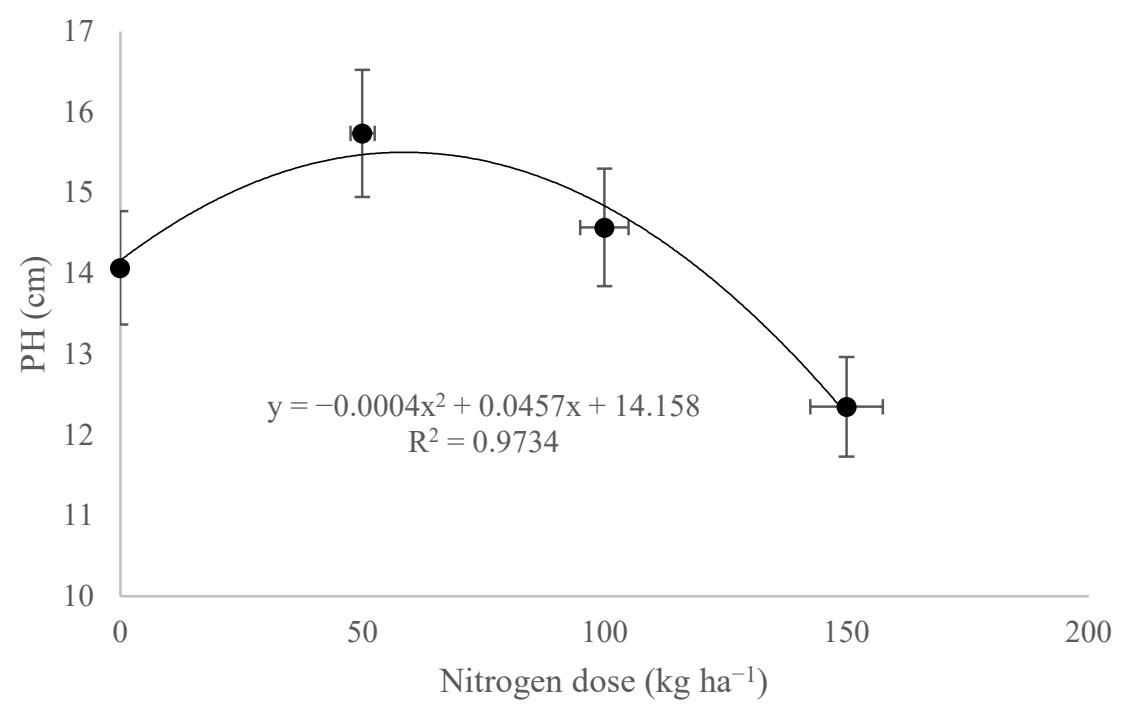

FIGURE 3. Height of jambu plants as a function of different nitrogen doses $\left(0,50,100\right.$, and $\left.150 \mathrm{~kg} \mathrm{ha}^{-1}\right)$. 
Jambu production is benefited by the stress that maintains soil moisture close to field capacity. It is in accordance with Gusmão \& Gusmão (2013), who stated that jambu occurs naturally under humid conditions, being an important factor for its development.

Soil moisture in the treatment with the stress of 12 $\mathrm{kPa}$ was maintained by applying low water depths with low irrigation frequency, which favored photoassimilates absorption and soil aeration, and hence better vegetative development. Nitrogen dose of $150 \mathrm{~kg} \mathrm{ha}^{-1}$ provided better results when associated with the stress of $12 \mathrm{kPa}$. It is possibly due to an increase in the split of water supply to the plant, which may have favored nutrient absorption and decreased losses by leaching. Productivity reduction as stress increases may be related to a higher amount of water applied at each irrigation time, as the leaching process may be favored under these conditions.

Borges et al. (2014) found productivity of $29.8 \mathrm{tha}^{-1}$ using a nitrogen dose of $69.9 \mathrm{~g} \mathrm{~m}^{2}$. This productivity was lower than that found in this study, but a higher amount of nitrogen fertilizer was used to conduct the experiment. The difference in productivity between studies may be related to the planting density adopted by Borges et al. (2014), as the fresh matter cited was higher than that found in the present study.

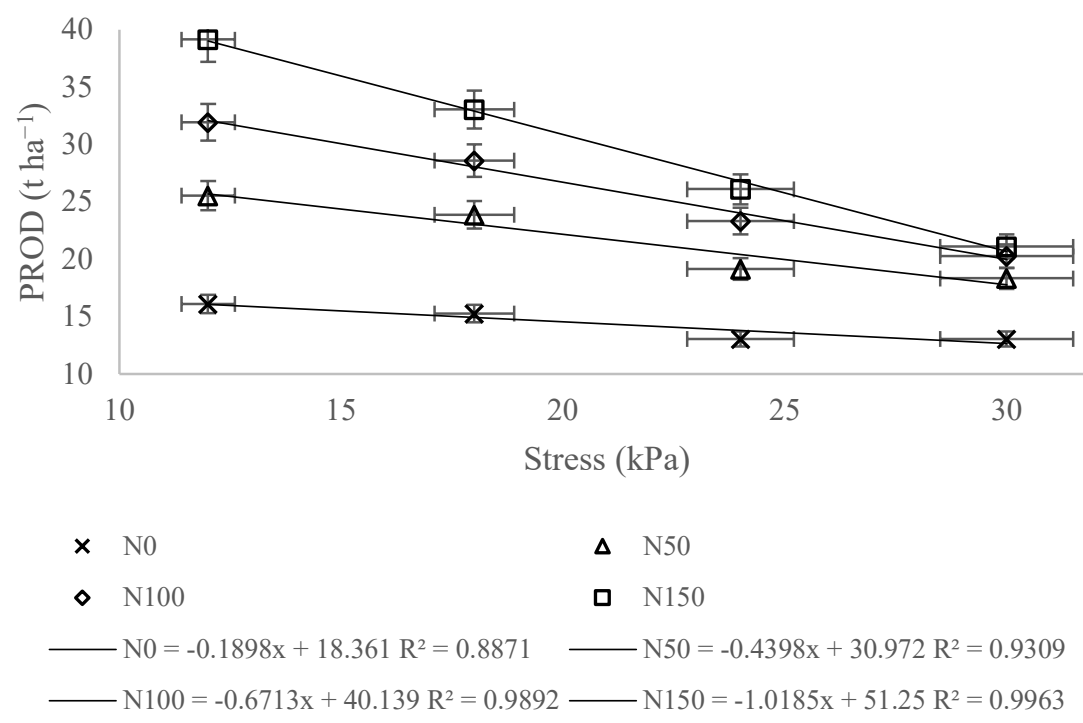

FIGURE 4. Jambu productivity as a function of different soil-water stress $(12,18,24$, and $30 \mathrm{kPa})$ and nitrogen doses $(0,50$, 100 , and $\left.150 \mathrm{~kg} \mathrm{ha}^{-1}\right)$.

The nitrogen dose of $150 \mathrm{~kg} \mathrm{ha}^{-1}$, which allowed the maximum productivity found in this study, is higher than that recommended by Cravo et al. (2007), showing that leafy vegetables under tropical, climate, and soil conditions present higher water and nutritional requirements.

Water use efficiency is a variable that shows the relationship between water production and water consumption. This variable showed a decreasing linear behavior as soil-water stress increased (Figure 5). The maximum value obtained for water-use efficiency was $220.8 \mathrm{~kg} \mathrm{ha}^{-1} \mathrm{~mm}^{-1}$, obtained with a stress of $12 \mathrm{kPa}$, which had the highest total irrigation depth, and a nitrogen dose of $150 \mathrm{~kg} \mathrm{ha}^{-1}$. The other stresses combined with fertilization of $150 \mathrm{~kg} \mathrm{ha}^{-1}$ had lower water use efficiencies, i.e., stresses of 18,24 , and $30 \mathrm{kPa}$ reached $193.6,166.3$, and $139.0 \mathrm{~kg}$ $\mathrm{ha}^{-1} \mathrm{~mm}^{-1}$, respectively.

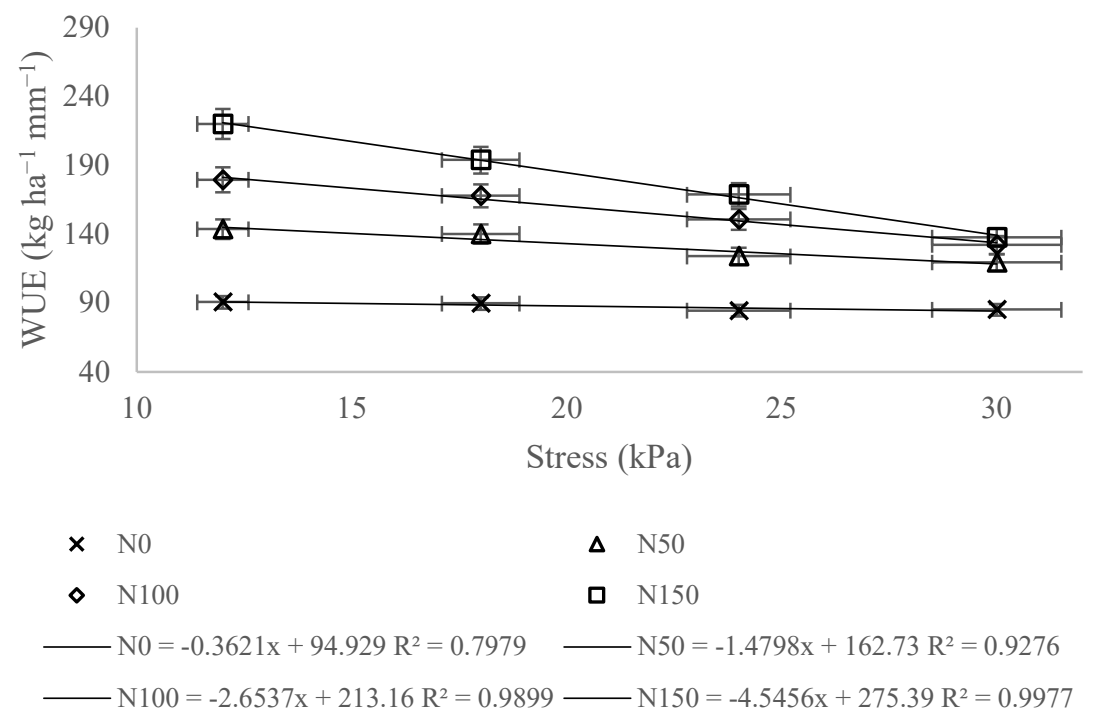

FIGURE 5. Water use efficiency of jambu shoot fresh matter as a function of different soil-water stresses (12, 18, 24, and 30 $\mathrm{kPa})$ and nitrogen doses $\left(0,50,100\right.$, and $\left.150 \mathrm{~kg} \mathrm{ha}^{-1}\right)$. 
Water use efficiency is a strategy for the rational use of water resources. However, jambu productivity decreased as the total applied water depth decreased. This behavior shows the positive response of jambu to an increase in the applied water depths. Similar to the results found in this study, Silva et al. (2013) evaluated water-use efficiency in beet cultivars under different soil water stresses and Sahin et al. (2016) evaluated lettuce production submitted to different irrigation levels and found that the efficiency in water use reduced with a reduction of the applied water depths.

\section{CONCLUSIONS}

The use of the soil-water stress of $12 \mathrm{kPa}$ associated with nitrogen fertilization at a dose of $150 \mathrm{~kg} \mathrm{ha}^{-1}$ is recommended for better development and production of jambu under the conditions this experiment was conducted.

\section{ACKNOWLEDGMENTS}

The authors thank CNPq (National Council for Scientific and Technological Development) for financing this research and granting the scholarship. To the Federal Rural University of Amazonia (UFRA) and the Basic and Applied Research Center for Irrigated Agriculture (NPBAAI).

\section{REFERENCES}

Andrade Junior AS, Bastos EA, Maschio R, Silva EM (2007) Determinação da curva de retenção de água no solo em laboratório. Teresina, Embrapa Meio Norte.

Araújo BA, Demontiêzo FLL, Araújo DA, Silva ES, Valnir Junior M, Moreira FJC (2018) Desenvolvimento de eruca sativa 1. sob diferentes lâminas de irrigação e substratos. Revista Brasileira de Agricultura Irrigada 12(4)2731-2739. DOI:

http://dx.doi.org/10.7127/rbai.v12n400964

Aviz WLC, Lima Junior JA, Silva ALP, Gomes RF, Souza RORM, Santos HCA, Oliveira PD (2019) Productivity of jambu (Acmella oleracea) using different soil water tensions and nitrogen rates under greenhouse condition. Australian Journal of Crop Science 3(3):360-366. DOI: http://dx.doi.org/10.21475/ajcs.19.13.03.p1178

Azevedo BM, Sousa GG, Paiva TFP, Mesquita JBR, Viana TVA (2014) Manejo da irrigação na cultura do amendoim. Magistra 26(1):11-18.

Barbosa AF, Carvalho MG, Smith RE, Sabaa-Srur AUO (2016) Spilanthol: occurrence, extraction, chemistry and biological activities. Revista Brasileira de Farmacognosia 26:128-133. DOI:

http://dx.doi.org/10.1016/j.bjp.2015.07.024

Borges LS, Goto R, Lima GPP (2014) Índices morfofisiológicos e produtividade de cultivares de jambu influenciadas pela adubação orgânica e mineral. Bioscience Journal 30(6)1768-1778.

Calgaro M, Braga MB (2008) Determinação da uniformidade de distribuição de água em sistema de irrigação localizada. Petrolina, Embrapa Semi-Árido.
Cravo MS, Viégas IJM, Brasil EC (2007) Recomendações de adubação e calagem para o Estado do Pará. Belém, Embrapa Amazônia Oriental.

Dutra AF, Melo AS, Brito MEB, Suassuna JF, Dutra WF (2018) Photochemical and productive performance of yellow passion fruit irrigated in the brazilian semiarid. Engenharia Agrícola 38(6):901-909. DOI:

http://dx.doi.org/10.1590/1809-430Eng.Agric.v38n6p901909/2018

Farias MF, Meneses KC, Soares FA, Santos RA, Dias RM, Bonfim MAD (2015) Produtividade de cultivares de alface sob adubação nitrogenada e borratada. Acta Iguazu 4(3): 116-125.

Favoreto R, Gilbert B (2010) Acmella oleracea (L.) R. K. Jansen (Asteraceae) - Jambu. Revista Fitos, 5(1).

Foley JA, Ramankutty N, Brauman KA, Cassidy ES, Gerber JS, Johnston M, Mueller ND, O’Connell C, Ray DK, West PC, Balzer C, Bennett EM, Carpenter RS, Hill J, Monfreda C, Polasky S, Rockstro MJ, Sheehan J, Siebert S, Tilman D, Zaks DPM (2011) Solutions for a cultivated plantet. Nature 478:337-342.

Geisenhoff LO, Pereira GM, Lima Junior JA, Silva ALP, Aviz WLC (2016) Greenhouse crisphead lettuce grown with mulching and under different soil water tensions. Engenharia Agrícola 36(1):46-54. DOI:

http://dx.doi.org/10.1590/1809-4430-Eng.Agric.v36n1p46$54 / 2016$

Gusmão MTA, Gusmão SAL (2013) Jambu da Amazônia (acmella oleraceae [(L.) R.K. Jansen] Características gerais, cultivo convencional, orgânico e hidropônico. Belém, UFRA, $135 \mathrm{p}$.

Lima Junior JA, Pereira GM, Geisenhoff LO, Vilas Boas RC, Silva WG, Silva ALP (2012) Produtividade da alface americana submetida a diferentes lâminas de irrigação. Semina: Ciências Agrárias 33(supl 1):2681-2688. DOI: DOI: http://dx.doi.org/10.5433/16790359.2012v33Sup11p2681

Marouelli WA, Oliveira ÁS DE, Coelho EF, Nogueira LC, Sousa VF (2014) Manejo da água de irrigação. In: Sousa VF, Marouelli WA, Coelho EF, Pinto JM, Coelho filho MA (eds). Irrigação e fertirrigação em fruteiras e hortaliças. 2. Brasília, DF, Embrapa Informação Tecnológica, 2 ed.

Mota JH, Silva CCR, Yuri JE, Resende GM (2016) Produção de alface americana em função da adubação nitrogenada nas condições de primavera em Jataí-GO. Revista de Agricultura 91(2):156-164.

Pacheco NA, Bastos TX (2011) Boletim agrometeorológico de 2008 para Igarapé-Açu, PA. Belém, Embrapa Amazônia Oriental. (Documento, 372)

Rezende R, Souza RS, Maller A, Freitas PSL, Gonçalves ACA, Rezende GS (2017) Produção e qualidade comercial de alface fertirrigada com nitrogênio e potássio em ambiente protegido. Revista Ceres 64(2):205-211. DOI: http://dx.doi.org/10.1590/0034-737X201764020014 
Rodrigues DS, Camargo MS, Nomura ES, Garcia VA, Correa JN, Vidal TCM (2014) Influencia da adubação com nitrogênio e fósforo na produção de Jambu, Acmella oleracea (L) R.K. Jansen. Revista Brasileira de Plantas Medicinais 16(1):71-76.

Sahin U, Kuslu Y, Kiziloglu FM, Cakmakci T (2016) Growth, yield, water use and crop quality response of lettuce to different irrigation quantities in a semi-arid region of high altitude. Journal of applied horticulture 18(3):195-202.

Silva AO, Silva EF, Klar AE (2013) Eficiência de uso da água em cultivares de beterraba submetidas a diferentes tensões de água no solo. Water Resources and Irrigation Management 2(1):27-36. DOI:

http://dx.doi.org/10.1590/S0102-053620150000100003
Souto GC, Grangeiro LC, Gusmão SAL, Sousa VFL, Cavalcante AEC, França FD (2018) Agronomic performance of jambu (Acmella oleracea) using organic fertilization. Australian Journal of Crop Science 12(1):151156. DOI: http://dx.doi.org/10.21475/ajcs.18.12.01.pne819

Van Genuchten MT (1980) A closed form equation for predicting the hydraulic conductivity of unsaturated soils. Soil Science Society of America Journal 44:892-898.

Valeriano TTB, Santana MJ, Oliveira AF, Machado LJM (2016) Alface americana cultivada em ambiente protegido submetida a doses de potássio e lâminas de irrigação. Irriga 21(3):620-630.

Vieira Filho OS, Oliveira GQ, Biscaro GA, Motomiya AVA, Geisenhoff LA (2017) Fertirrigação com nitrogênio na cultura da rúcula. Revista Agrarian 10(38):304-310. 